\title{
Role of airway receptors in the breathing pattern of patients with chronic obstructive lung disease
}

\author{
AG FENNERTY, J BANKS, C BEVAN, AP SMITH \\ From the Department of Thoracic Medicine and the Medical Research Council Pneumoconiosis Unit, \\ Llandough Hospital, Penarth, South Glamorgan
}

ABSTRACT To determine whether airway receptors are responsible for the rapid, shallow breathing pattern seen in hypercapnic chronic obstructive lung disease, 10 patients underwent upper airway anaesthesia with inhaled lignocaine in a placebo controlled study. There was a significant reduction in breathing frequency after lignocaine $(p<0.001)$ that was due to an increase in expiratory time $(p<0.001)$. The inspiratory time remained unchanged, but tidal volume increased significantly $(\mathrm{p}<0.02)$. It is concluded that, while airway receptors may have a role in determining the frequency of breathing in chronic obstructive lung disease, other factors are responsible for the reduced inspiratory time.

The mechanism of carbon dioxide retention in chronic irreversible obstructive airways disease is not fully understood. While patients with hypercapnia tend to have a low $\mathrm{FEV}_{1}$, there are many with similar degrees of airways obstruction who remain normocapnic.' When these two groups are compared, however, carbon dioxide retainers are found to have a higher breathing frequency, a shorter inspiratory time, and a lower tidal volume than normocapnic patients, resulting in a greater degree of ventilatory dead space and alveolar hypoventilation. ${ }^{1-5}$ Since most patients with carbon dioxide retention are found to have chronic bronchitis and chronic obstructive lung disease, it has been suggested that vagally mediated lung receptors may be hyperactive as a result of bronchial inflammation and serve to terminate inspiration prematurely, resulting in a reduced tidal volume and a compensatory increase in breathing frequency. ${ }^{246}$ Inhaled histamine in normal subjects and animals can induce the rapid, shallow breathing pattern seen in chronic obstructive lung disease, ${ }^{67}$ presumably via airway receptor stimulation that decreases both inspiratory and expiratory time; while similar breathing patterns associated with a chemically induced lobar inflammation in cats and rabbits were abolished after selective vagotomy. ${ }^{8}$

Address for reprint requests: Dr AG Fennerty, Department of Thoracic Medicine, Llandough Hospital, Penarth, S Glam CF6 1XX.

Accepted 12 November 1984
We have investigated the role of airway receptors in the breathing pattern of hypercapnic patients with chronic obstructive lung disease.

\section{Methods}

Ten stable hospital inpatients (six of them women) with chronic obstructive lung disease, a history of chronic bronchitis, and carbon dioxide retention participated in the study. They gave their full consent and ethical approval for the study was obtained from the local ethical committee.

In seven patients breathing patterns were measured with the subjects breathing through a mouthpiece attached to a pneumotachograph (Mercury), which had a linear response up to $250 \mathrm{~V} / \mathrm{min}$. Airflow was integrated to give volume. Airflow, volume, and a 0.5 second time signal were recorded on a multichannel recorder (Mingograph). The volume signal was calibrated with a one litre displacement syringe before and after each procedure. Measurements of breathing frequency, inspiratory and expiratory time, and tidal volume were made manually from the recording, the end of expiration and inspiration corresponding to periods of zero flow. Subjects breathed quietly on the apparatus for three minutes before recordings were made over a period of five minutes. All patients were seated comfortably in a quiet room with headphones playing music. Immediately after the first recording, patients were given either normal saline placebo or $4 \%$ lignocaine, 
Table 1 Details of 10 patients

\begin{tabular}{|c|c|c|c|c|c|}
\hline $\begin{array}{l}\text { Patient } \\
\text { No }\end{array}$ & $\begin{array}{l}\text { Age } \\
(y)\end{array}$ & $\underset{(l)}{F E V_{1}}$ & $\underset{(l)}{F V C}$ & $\begin{array}{l}\mathrm{PaCO} \\
(\mathrm{kPa})^{2}\end{array}$ & $\begin{array}{l}\mathrm{PaO}_{3} \\
(\mathrm{kPa})\end{array}$ \\
\hline $\begin{array}{c}1 \\
2 \\
3 \\
4 \\
5 \\
6 \\
7 \\
8 \\
9 \\
10 \\
\text { Mean } \\
\text { SD }\end{array}$ & $\begin{array}{r}66 \\
67 \\
70 \\
68 \\
62 \\
54 \\
63 \\
57 \\
62 \\
60 \\
63 \\
5\end{array}$ & $\begin{array}{l}0.53 \\
0.70 \\
0.65 \\
0.31 \\
0.75 \\
0.35 \\
0.69 \\
0.77 \\
0.52 \\
0.35 \\
0.56 \\
0.17\end{array}$ & $\begin{array}{l}1.30 \\
1.50 \\
1.20 \\
0.89 \\
2.0 \\
0.9 \\
0.69 \\
1.75 \\
0.95 \\
1.5 \\
1.24 \\
0.44\end{array}$ & $\begin{array}{l}7.2 \\
6.1 \\
7.5 \\
9.3 \\
7.6 \\
6.8 \\
6.9 \\
6.9 \\
8.0 \\
6.7 \\
7.4 \\
0.83\end{array}$ & $\begin{array}{l}6.7 \\
8.7 \\
7.9 \\
6.9 \\
6.5 \\
7.2 \\
9.3 \\
8.3 \\
7.9 \\
7.7 \\
7.7 \\
0.89\end{array}$ \\
\hline
\end{tabular}

$\mathrm{PaCO}_{2}$ arterial carbon dioxide tension.

$\mathrm{PaO}_{2}$ arterial oxygen tension.

Conversion: SI to traditional units-Blood gas tensions: $1 \mathrm{kPa}=7.5 \mathrm{~mm} \mathrm{Hg}$.

in random order via a mouthpiece attached to a Hudson nebuliser powered by air at a pressure of 15 $\mathrm{lb} / \mathrm{in}^{2}(103.5 \mathrm{kPa})$ for 12 minutes. After the patient had inhaled the lignocaine, anaesthesia of the upper airways was verified: if he or she coughed on inhaling a nebulised solution of $10 \% \mathrm{w} / \mathrm{v}$ citric acid lignocaine was administered for a further two minutes and the challenge repeated. All patients were adequately anaesthetised after 14 minutes' inhalation. The procedure could not be double blind as patients had to be warned of the effects of pharyngeal anaesthesia and all remarked on the unpleasant taste of lignocaine. None of them was aware, however, of the nature of the experiment. The recordings were repeated at the same time the following day before and after the second of the two solutions had been inhaled.

For three patients who would not tolerate a mouthpiece recordings were made with a pressure capsule sealed over the suprasternal notch. Inspiration produced a negative pressure wave, which was recorded on the multichannel recorder via a Statham PM131 pressure transducer. As this was simply an indicator signal it was not calibrated and only respiratory frequency was analysed in these three patients.

The five minute recordings were analysed in 30 second strips and the final breathing frequency, tidal volume, and inspiratory and expiratory times for each run were derived from the means of these measurements. Recordings were analysed by an independent observer, single blind, and the difference between measurements before and after the placebo inhalation were compared with those before and after lignocaine, Students $t$ test for paired samples being used.

Table 2 Breathing frequency (breaths/min) before and after inhalation of placebo and lignocaine in 10 hypercapnic patients with chronic obstructive lung disease

\begin{tabular}{lllll}
\hline $\begin{array}{l}\text { Patient } \\
\text { No }\end{array}$ & $\begin{array}{l}\text { Before } \\
\text { placebo }\end{array}$ & $\begin{array}{l}\text { After } \\
\text { placebo }\end{array}$ & $\begin{array}{l}\text { Before } \\
\text { lignocaine }\end{array}$ & $\begin{array}{l}\text { After } \\
\text { lignocaine }\end{array}$ \\
\hline Using mouthpiece & & & & 24.1 \\
1 & 27.3 & 29.4 & 28.8 & 23.5 \\
2 & 24.7 & 25.2 & 24.2 & 24.5 \\
3 & 21.0 & 22.2 & 25.7 & 27.7 \\
4 & 29.4 & 48.4 & 33.4 & 25.6 \\
5 & 45.0 & 29.1 & 27.0 & 26.6 \\
6 & 26.0 & 26.0 & 27.1 & $1.0)$ \\
7 & 24.6 & $30.2(3.2)$ & $27.7(2.9)$ & 16.2 \\
Mean (SEM) & $28.3(2.9)$ & 19.4 & 20.2 & 12.6 \\
Using suprasternal pressure capsule & 20.0 & 23.8 & 23.4 & $17.7(3.47)$ \\
8 & 24.8 & 26.4 & 25.4 & $22.4(1.5)$ \\
9 & 25.5 & $23.2(2.05)$ & $26.8(1.41)$ & $-3.88(1.03)^{* * *}$ \\
Mean (SE) & $23.4(1.73)$ & $28.1(2.5)$ & $26.3(1.1)$ & \\
Mean for combined data & $26.8(2.2)$ & $+1.4(0.9)$ & & \\
(SE) & & & \\
Mean difference (SE) & & & \\
\hline
\end{tabular}

${ }^{* * *} \mathrm{p}<0.001$ for comparison of the difference between before and after placebo with the difference between before and after lignocaine. 
Table 3 Inspiratory and expiratory time and tidal volume in seven hypercapnic patients using the mouthpiece

\begin{tabular}{|c|c|c|c|c|c|c|c|c|c|c|c|c|}
\hline \multirow{2}{*}{$\begin{array}{l}\text { Patient } \\
\text { No }\end{array}$} & \multicolumn{4}{|c|}{ Inspiratory time (s) } & \multicolumn{4}{|c|}{ Expiratory time (s) } & \multicolumn{4}{|c|}{ Tidal volume $(\mathrm{ml})$} \\
\hline & $\boldsymbol{B P}$ & $A P$ & $B L$ & $A L$ & $\boldsymbol{B P}$ & $\boldsymbol{A P}$ & $B L$ & $A L$ & $\boldsymbol{B P}$ & $\boldsymbol{A P}$ & $B L$ & $A L$ \\
\hline $\begin{array}{l}1 \\
2 \\
3 \\
4 \\
5 \\
6 \\
7 \\
\text { Mean } \\
\text { SE }\end{array}$ & $\begin{array}{l}0.79 \\
0.9 \\
1.09 \\
0.79 \\
0.53 \\
0.79 \\
0.93 \\
0.83 \\
0.07\end{array}$ & $\begin{array}{l}0.75 \\
0.89 \\
1.2 \\
0.73 \\
0.51 \\
0.71 \\
0.88 \\
0.81 \\
0.08\end{array}$ & $\begin{array}{l}0.85 \\
0.93 \\
1.58 \\
1.41 \\
0.70 \\
0.77 \\
0.80 \\
1.01 \\
0.13\end{array}$ & $\begin{array}{l}0.83 \\
0.86 \\
2.03 \\
1.61 \\
0.67 \\
0.73 \\
0.83 \\
1.08 \\
0.20\end{array}$ & $\begin{array}{l}1.55 \\
1.72 \\
1.94 \\
1.47 \\
0.91 \\
1.74 \\
1.66 \\
1.57 \\
0.12\end{array}$ & $\begin{array}{l}1.55 \\
1.69 \\
1.2 \\
1.35 \\
0.86 \\
1.56 \\
1.61 \\
1.40 \\
0.11\end{array}$ & $\begin{array}{l}1.59 \\
1.72 \\
0.99 \\
0.89 \\
1.23 \\
1.66 \\
1.57 \\
1.38 \\
0.13\end{array}$ & $\begin{array}{l}1.74 \\
1.90 \\
1.14 \\
0.99 \\
1.66 \\
1.68 \\
1.60 \\
1.52^{* * *} \\
0.13\end{array}$ & $\begin{array}{r}432 \\
597 \\
437 \\
223 \\
398 \\
491 \\
660 \\
462 \\
54\end{array}$ & $\begin{array}{r}434 \\
567 \\
389 \\
202 \\
365 \\
458 \\
636 \\
435 \\
53\end{array}$ & $\begin{array}{r}456 \\
597 \\
418 \\
230 \\
509 \\
230 \\
580 \\
431 \\
57\end{array}$ & $\begin{array}{l}476 \\
564 \\
415 \\
256 \\
558 \\
219 \\
640 \\
447^{*} \\
60\end{array}$ \\
\hline
\end{tabular}

${ }^{*} \mathrm{p}<0.02 ;{ }^{* * *} \mathrm{p}<0.001$ for comparison of BP-AP with BL-AL.

$\mathrm{BP}$-before placebo; AP-after placebo; $\mathrm{BL}$-before lignocaine; $\mathrm{AL}$-after lignocaine.

\section{Results}

Details of the 10 patients are given in table 1 . Breathing frequency was analysed from the values obtained for the seven patients breathing through a mouthpiece and the three using a suprasternal pressure capsule (table 2). Analysis of inspiratory and expiratory time and tidal volume was limited to the seven patients using a mouthpiece.

There was a significant reduction in breathing frequency in the 10 patients when rates before and after placebo were compared with rates before and after lignocaine $(p<0.001)$ (table 2$)$. The seven patients using the mouthpiece showed a significant increase in tidal volume $(\mathrm{p}<0.02)$ and expiratory time ( $p<0.001)$ (table 3$)$. There was no significant change in inspiratory time. Five patients received placebo first and no order effect on the results was observed. Patient 5 had a very rapid respiratory rate, particularly on day 1 (placebo run). Elimination of this subject, however, had no overall effect on the results.

\section{Discussion}

The rapid, shallow breathing pattern of hypercapnic patients with chronic obstructive lung disease and chronic bronchitis can be modified by inhaled nebulised lignocaine. Breathing frequency is reduced owing to an increase in expiratory time and we postulate that this is due to blocking of lung receptors.

There are three known groups of receptor in the lung: the myelinated stretch and irritant receptors and the non-myelinated $C$ fibre mediated receptors, whose role is as yet uncertain but which include the so called $\mathrm{J}$ receptors. Stimulation of irritant and $\mathrm{C}$ fibre receptors has been shown to induce rapid, shatlow breathing in animals and man, with reduction in both inspiratory and expiratory times. ${ }^{68}$ Blocking these receptors should increase both inspiratory and expiratory times if they are important in influencing the breathing pattern of patients with chronic bronchitis. Stretch receptors are thought to have little influence on the breathing pattern of normal individuals at rest; only when the tidal volume is more than one and a half times to twice the resting value do volume related receptors act to terminate inspiration, preventing further increases in tidal volume." The duration of inspiratory time seems to be set by a central mechanism and remains constant over a wide range of tidal volumes, changes in breathing frequency occurring mainly through changes in expiratory time..$^{10}$ Tonic discharge from stretch receptors at high lung volumes serve to prolong expiratory time. " Stretch receptors may conceivably have a more important role in controlling breathing patterns in patients with chronic obstructive lung disease who breathe at high lung volumes, shortening inspiratory time but prolonging expiratory time. Since expiratory time was prolonged, not shortened as might have been expected if stretch receptors had been blocked by lignocaine, we deduce that the fall in breathing frequency is due to blocking of afferent impulses from irritant or $\mathrm{C}$ fibre receptors or both. Failure to show a significant increase in inspiratory time may be due to overriding central influences.

Murciano et al obtained results similar to ours in patients with chronic obstructive lung disease in acute respiratory failure in an intensive care unit. ${ }^{12}$ Lignocaine was delivered via a fibreoptic broncho- $\sigma$ scope. Patients became more hypoxic after ligno- $N$ caine, and this was thought to be due to worsening ventilation-perfusion imbalance; the resulting increase in respiratory drive, as measured by $\mathbf{P}_{0 \cdot 1}$, was probably responsible for the increase in tidal volume. Blood gas tensions were not measured in our patients but any hypoxia induced by lignocaine would explain the rise in tidal volume.

The unsatisfactory method of measuring the respiratory cycle with a mouthpiece in patients with respiratory disease is highlighted in this study. All patients found the procedure unpleasant and the 
increase in breathing frequency and reduction in tidal volume and expiratory time observed after placebo is probably due to progressive stress since this effect was not observed in patients using the suprasternal pressure capsule, a relatively stress free procedure.

In conclusion, our study suggests that the rapid, shallow breathing pattern of hypercapnic patients with chronic obstructive lung disease is only partially under the influence of afferent discharges from irritant or $\mathrm{C}$ fibre receptors or both, which increase breathing frequency by reducing expiratory time. Since inspiratory time is unchanged after blocking of airway receptors inspiratory time is likely to be set, as in health, by a central mechanism rather than by discharges from lung receptors.

\section{References}

1 Parot S, Saunier C, Gautier H, Milic-Emili J, Sadoul P. Breathing pattern and hypercapnoea in patients with obstructive pulmonary disease. Am Rev Respir Dis 1980;121:985-91.

2 Sorli J, Grassino A, Lorange G, Milic-Emili J. Control of breathing in patients with chronic obstructive lung disease. Clin Sci Mol Med 1978;54:295-304.

3 Skatrud JB, Dempsey JA, Bhansoli P, Irvin C. Determinants of chronic carbon dioxide retention and its correction in humans. J Clin Invest 1980;65:813-21.

4 Aubier M, Marciano D, Fournier M, Milic-Emili J,
Pariente $\mathbf{R}$, Darenne JP. Central respiratory drive in acute respiratory failure of patients with chronic pulmonary disease. Am Rev Respir Dis 1980;122:191-9.

5 Javaheri S, Blum J, Kasemi H. Pattern of breathing and carbon dioxide retention in chronic obstructive lung disease. Am J Med 1981;71:228-33.

6 Pardy RL, Rivington RN, Milic-Emili J, Martola JP. Control of breathing in chronic obstructive pulmonary disease - the effect of histamine inhalation. Am Rev Respir Dis 1982;125:6-11.

7 Miserocchi G, Trippenbach T, Missoreli M, Jaspar N, Macucha $M$. The mechanism of rapid shallow breathing due to histamine and phenyldiguanide in cats and rabbits. Respir Physiol 1978;32:141-53.

8 Trenchard D, Gardner D, Guz A. The role of pulmonary vagal afferent nerve fibres in the development of rapid shallow breathing in lung inflammation. Clin Sci 1972;42:251-63.

9 Clark FJ, Von Euler C. On the regulation of depth and rate of breathing. $J$ Physiol 1972;222:267-95.

10 Cunningham DJC, Gardner WN. A quantative description of the pattern of breathing during steady state $\mathrm{CO}_{2}$ inhalation in man, with special emphasis on expiration. J Physiol 1977;272:613-32.

11 Bartoli A, Bystryzycka E, Guz A, Jain SK, Noble MIM, Trenchard D. Studies of the pulmonary vagal control of central respiratory movement in the absence of breathng movements. J Physiol 1973;230:449-65.

12 Murciano D, Aubier M, Vian F, et al. Effects of airway anaesthesia on pattern of breathing and blood gases in patients with chronic obstructive pulmonary disease during acute respiratory failure. Am Rev Respir Dis 1982;126: 113-7. 